\title{
Lamothe-Montravel - La Fraîchière, Les Baillargats, La Grande Pièce
}

$n^{\circ} 026137$

Jean-François Chopin

\section{OpenEdition}

Journals

Édition électronique

URL : http://journals.openedition.org/adlfi/16409

ISSN : 2114-0502

Éditeur

Ministère de la culture

\section{Référence électronique}

Jean-François Chopin, «Lamothe-Montravel - La Fraîchière, Les Baillargats, La Grande Pièce », ADLFI.

Archéologie de la France - Informations [En ligne], Aquitaine, mis en ligne le 10 février 2016, consulté le

01 mai 2019. URL : http://journals.openedition.org/adlfi/16409

Ce document a été généré automatiquement le 1 mai 2019.

(c) Ministère de la Culture et de la Communication, CNRS 


\title{
Lamothe-Montravel - La Fraîchière, Les Baillargats, La Grande Pièce $\mathrm{n}^{\circ} 026137$
}

\author{
Jean-François Chopin
}

Lien Atlas (MCC) :

http://atlas.patrimoines.culture.fr/atlas/trunk/index.php?

ap_theme=DOM_2.01.02\&ap_bbox=-0.035;44.824;0.054;44.869

1 Ce diagnostic archéologique s'inscrit dans le cadre de l'extension des carrières de granulats sur les terrasses de la Dordogne. L'emprise totale du projet couvre une superficie de $7508 \mathrm{~m}^{2}$, sondée à hauteur de 5,9\%.

2 Sur le plan archéologique, ce projet est implanté dans un secteur où de nombreux sites archéologiques ont été recensés dans la carte archéologique nationale. En périphérie immédiate de ce projet, plusieurs sites, notamment néolithiques et protohistoriques, ont été repérés à l'occasion de recherches anciennes (Ferrier, 1949) ou dans le cadre de diagnostics réalisés par l'Inrap (Briand, 2002 ; Sandoz, 2004 ; Augry, 2004).

3 Cette opération confirme la présence d'occupations néolithiques et protohistoriques dans l'emprise du projet. Cependant, ces dernières sont peu denses et elles ont été affectées par des activités agricoles d'époque contemporaine. Mise à part la découverte de quelques fosses et d'un foyer à galets, seuls des épandages de mobiliers céramique et lithique remaniés ont été mis au jour lors de nos recherches. Ces quelques résultats font néanmoins progresser notre connaissance sur l'occupation néolithique et protohistorique dans ce secteur de la plaine alluviale de la Dordogne. 


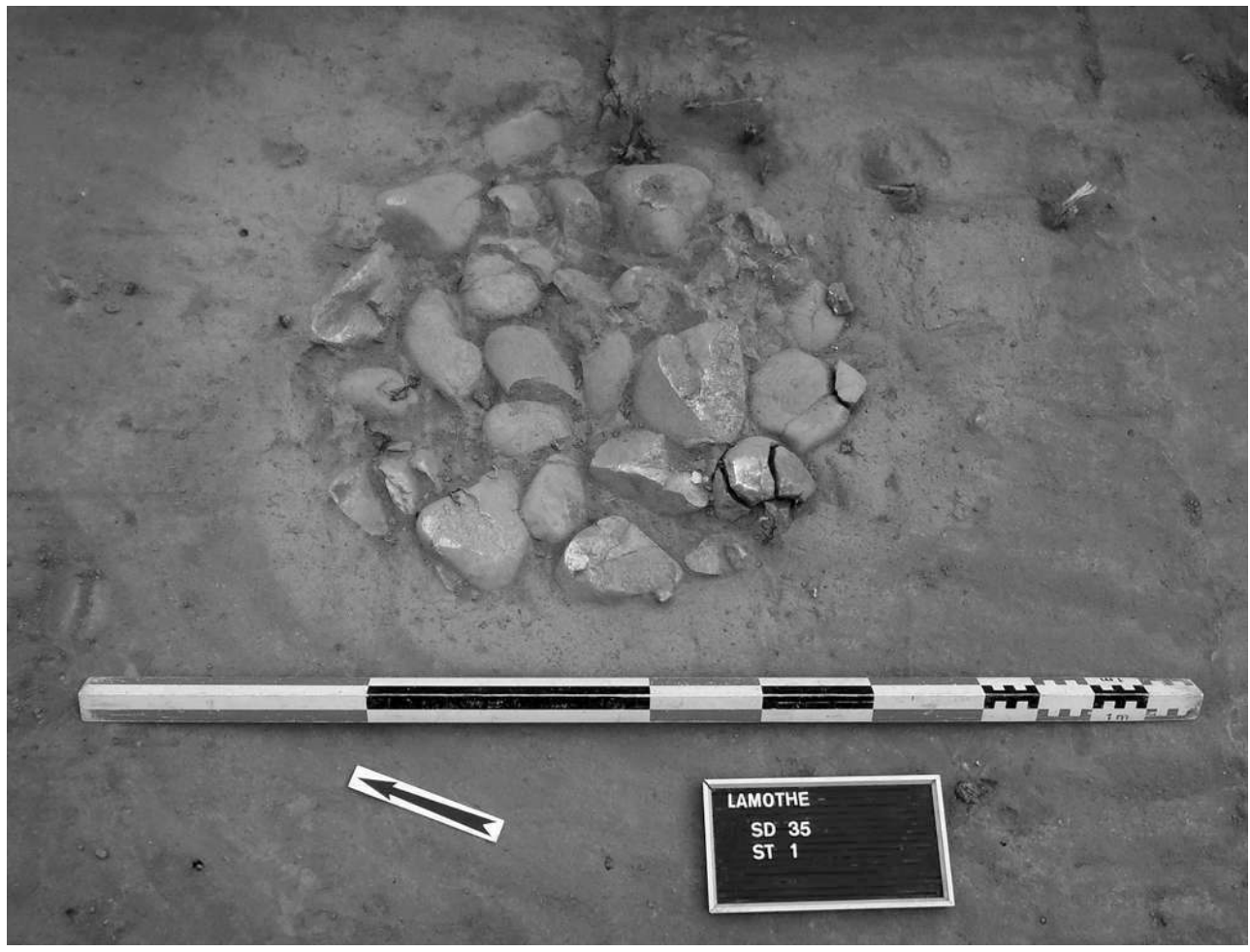

Fig. 1

Vue en perspective du foyer à galets

Cliché : J.-F. Chopin, Inrap.

INDEX

Index géographique : Aquitaine, Dordogne (24), Lamothe-Montravel operation Opération préventive de diagnostic (OPD)

\section{AUTEURS}

\section{JEAN-FRANÇOIS CHOPIN}

Inrap 